\title{
Mineralogical characterization of clays used in the structural ceramic industry in west of S. Paulo State, Brazil
}

\section{(Caracterização mineralógica de argilas usadas na indústria de cerâmica estrutural no oeste do estado de S. Paulo, Brasil)}

\author{
S. R. Teixeira, S. A. de Souza, C. A. I. Moura \\ Universidade Estadual Paulista-UNESP, P.O. Box 467 \\ Presidente Prudente, SP, Brazil, 19060-080
}

\begin{abstract}
Plasticity and the grain-size distribution of the raw material used to make structural bricks and roof tiles are very important to the production process. These two parameters and the mineral composition will define the quality and properties of the final product: color, mechanical resistance, water absorption, cracks, swell and shrink during drying and firing the ceramic pieces etc. In the Brazilian ceramic industry it is very common to mix together two or more different kinds of raw material to achieve the ceramic mass with the desired grain-size distribution. The objective of this work was to characterize the raw material collected at the floodplains of the Paraná and Paranapanema Rivers and the ceramic mass used by the ceramic industry in western São Paulo State, Brazil. Particle size distribution, organic matter and X-ray diffraction were used to study this material. The textural analysis indicates that the raw materials have the clay fraction ranging from $38.2 \%$ to $66.3 \%$, the silt from $22.2 \%$ to $49.7 \%$ and the sand from $3.1 \%$ to $34.1 \%$. The results indicate that all mixed raw materials have more clay in its composition than would be necessary. The organic matter ranges from 5 to $7 \%$. All samples have kaolinite and many of them have smectites, HIV and mica. Gibbsite, iron and titanium oxides, and quartz are also identified. One of the samples (yellow) is rich in goethite.
\end{abstract}

Keywords: structural ceramics, bricks, mineralogy, clays.

\section{INTRODUCTION}

The Paranapanema River is the borderline between São Paulo and Paraná states. There are more than 15 small and middle ceramic industries that have been using the material from deposits made of raw material collected in the floodplains of Paranapanema River. These deposits were made before the floodplains had been inundated when the Rosana Hydroelectric

\section{Resumo}

A plasticidade e a granulometria da massa cerâmica são dois parâmetros importantes para o processo de produção de tijolos e telhas. Estes dois parâmetros e a composição mineralógica definirão a qualidade e propriedades (cor, resistência mecâni$c a$, absorção de água, trincas, mudanças nas dimensões durante a secagem e queima, etc.) do produto final. Na indústria cerâmica brasileira é comum misturar dois ou mais tipos de "barro" para se obter a massa cerâmica com a granulometria e plasticidade desejada. O objetivo deste trabalho foi caracterizar a matéria prima coletada nas várzeas dos rios Paraná e Paranapanema e a massa cerâmica usada pela indústria cerâmica do oeste do Estado de São Paulo. Difratometria de raios $X$, análise textural, limite de plasticidade e concentração de matéria orgânica foram usadas para caracterizar as amostras. A análise textural mostra que a fração argila variou de 38,2 a 66,3\%, a fração silte de 22,2 a 49,7\% e a fração areia de 3,1 a 34,1\%. A concentração de matéria orgânica varia de 5 a $7 \%$. Os resultados de difração de raios $X$ mostram que todas as amostras possuem caulinita e muitas delas tem argilas do grupo das esmectitas, argilas interestratificadas e mica. Gibsita, óxidos de ferro e de titânio e quartzo são também identificados. Uma amostra usada para "pintar" potes é rica em goetita. Os resultados indicam que as massas cerâmicas tem alta concentração de argila na sua composição e devem ser misturadas com argila "magra". Caulinita é a fase majoritária em todas as amostras, dando uma boa plasticidade para a produção de tijolos e telhas por extrusão.

Palavras-chave: cerâmica vermelha, cerâmica estrutural, tijolos, mineralogia, argila.

Power Plant closed their floodgates, in 1985.

The Paraná River is the borderline between São Paulo and Mato Grosso do Sul states, Brazil. In both sides of this river there are more than 150 ceramic industries that consume each year more than 1.5 million cubic meters of raw material [1]. The raw material used by these ceramic industries is collected from the floodplain in both sides of the river. In all these industries two or more different materials are mixed together to achieve the desired plasticity and 
the grain-size distribution of the ceramic mass. These clays reservoirs are disappearing under the river water since (1998) when the floodgates of the "Porto Primavera" Dam (Hydroelectric Power Plant) begun to be closed.

The objective of this work is to characterize the raw material from the floodplains of the Paraná and Paranapanema Rivers and the ceramic mass used by the ceramic industry in western of São Paulo State - Brazil, to produce massive bricks, ceramic blocks, and roof tiles (Romany type).

\section{MATERIALS AND METHODS}

The industries have taken the raw material in the floodplains of the Paraná and Paranapanema Rivers banks, on the Bauru Sandstone. Eighteen samples were collected in industries of five different cities: Indiana (4), Martinópolis (1), Panorama (1), Presidente Epitácio (5) and Teodoro Sampaio (7). Seven of these samples are raw materials and the other eleven are ceramic mass. Seven are prepared to make structural bricks, one to make massive brick, one to make "Romana" roof tile and one to make pottery. There is one yellow raw material used to paint (give a red color after burn) the pottery. The raw materials used by the ceramics in Indiana (4) and Martinópolis (1) were not taken at the riverbanks. They were taken in floodplains around these cities.

The pipet method was applied to evaluate the samples texture [2]. The organic matter content of the samples was estimated by the Walkley-Black Method [3]. The sand was separated from silt and clay by sieving; the silt and clay were separated by centrifugation (Stoke's Law). The iron oxides were not removed. The samples for X-ray diffraction were prepared and analyzed according to Dixon \& White [4] and Moore and Reynolds [5]. The X-ray diffraction patterns were obtained on a Carl Zeiss/Jena diffractometer, HZG4/ $\mathrm{B}$ (quartz concavous-cylindrical monochromator and $\mathrm{CuK} \alpha$ radiation). Operating conditions of $40 \mathrm{kV}$ and $30 \mathrm{~mA}$ were used. The clays oriented on glass slides were $\mathrm{x}$-rayed step-by-step (0.05/ $0.05^{\circ}, 3 \mathrm{~s} /$ step). The X-ray data were collected and analyzed by using the program package APX63/POWDER.

The moisture of the samples was determined by weighting the samples (pressed and after dried at $110{ }^{\circ} \mathrm{C}$ ) and the Attenberg Plasticity Limit was determined according to ABNT [6].

\section{RESULTS AND DISCUSSION}

Table I shows the textural analysis results, natural moisture, plasticity limit and matter organic content of each sample. The textural analysis indicates that the eighteen samples have high clay concentrations ranging from $38.2 \%$ to $66.3 \%$, the silt ranges from $22.2 \%$ to $49.7 \%$ and the sand from $3.1 \%$ to $34.1 \%$. Table II shows ideal particle-size composition to ceramic mass according to the Winkler diagram [7]. Comparing the samples particle-size composition (Table I) with the ideal particle-size distribution (Table II) it can be observed that all samples have more clay than would

Table I - Samples origin, particle-size distribution, texture, moisture, plasticity limit and organic matter.

[Tabela I - Origem, granulometria, textura, humidade, limite de plasticidade e matéria orgânica, das dezoito amostras estudadas.]

\begin{tabular}{lcccccccc}
\hline Sample \# & $\begin{array}{c}\text { Material } \\
\text { origin }\end{array}$ & $\begin{array}{c}\text { Clay } \\
\%\end{array}$ & $\begin{array}{c}\text { Silt } \\
\%\end{array}$ & $\begin{array}{c}\text { Sand } \\
\%\end{array}$ & Texture & $\begin{array}{c}\text { Moisture } \\
\%\end{array}$ & $\begin{array}{c}\text { P. L. } \\
\%\end{array}$ & $\begin{array}{c}\text { O. M. } \\
\%\end{array}$ \\
\hline $01 \mathrm{R}$ & In. & 38.2 & 27.7 & 34.1 & Clay Loam & 9.7 & 22.2 & 5.29 \\
\hline $02 \mathrm{P}$ & In. & 49.0 & 34.4 & 16.5 & Clay & 5.1 & 28.3 & 5.00 \\
\hline $03 \mathrm{R}$ & In. & 61.7 & 29.4 & 08.8 & Clay & 7.0 & 32.6 & 3.67 \\
\hline $04 \mathrm{Y}$ & In. & 49.2 & 22.2 & 28.5 & Clay & 3.0 & 32.3 & 6.49 \\
\hline 05 R & Mar. & 46.6 & 34.5 & 18.8 & Clay & 4.7 & 25.6 & 4.40 \\
\hline 06 B & P. E. & 37.4 & 36.2 & 26.3 & Clay Loam & 2.3 & 20.7 & 6.18 \\
\hline 07 R & P. E. & 66.3 & 27.2 & 06.5 & Clay & 4.0 & 40.7 & 5.98 \\
\hline 08 B & P. E. & 57.0 & 37.0 & 06.0 & Clay & 3.4 & 40.6 & 5.57 \\
\hline 09 R & T. S. & 49.4 & 47.5 & 03.1 & Silty Clay & 5.0 & 29.4 & 5.53 \\
\hline 10 R & T. S. & 45.7 & 49.7 & 04.6 & Silty Clay & 4.4 & 28.9 & 5.10 \\
\hline 11 B & T. S. & 43.3 & 39.1 & 17.6 & Clay & 2.8 & 25.9 & 5.51 \\
\hline 12 B & T. S. & 36.3 & 37.1 & 26.5 & Clay Loam & 3.4 & 20.1 & 5.62 \\
\hline 13 R & T. S. & 43.9 & 36.4 & 19.6 & Clay & 6.6 & 23.3 & 5.53 \\
\hline 14 B & T. S. & 39.1 & 34.1 & 26.7 & Clay Loam & 2.8 & 20.2 & 6.12 \\
\hline 15 B & T. S. & 43.1 & 35.7 & 21.2 & Clay & 3.0 & 21.9 & 6.03 \\
\hline 16 B & P. E. & 53.5 & 43.0 & 03.5 & Silty Clay & 3.8 & 39.5 & 5.71 \\
\hline 17 T & P. E. & 42.8 & 38.4 & 18.8 & Clay & 4.0 & 27.2 & 4.53 \\
\hline 18 B & Pan. & 38.0 & 48.1 & 13.9 & Silty Clay Loam & 3.3 & 31.3 & 5.17 \\
\hline R & B brik & & & & & \\
\hline
\end{tabular}

$\mathrm{R}=$ raw material; $\mathrm{B}=$ brick mass, $\mathrm{T}=$ roof tile mass, $\mathrm{P}=$ pottery, $\mathrm{Y}=$ yellow material, $\mathrm{P} . \mathrm{L} .=$ Plasticity limit, In.=Indiana, Mar.= Martinópolis, P.E.= Presidente Epitácio, T.S.= Teodoro Sampaio and Pan.= Panorama. 

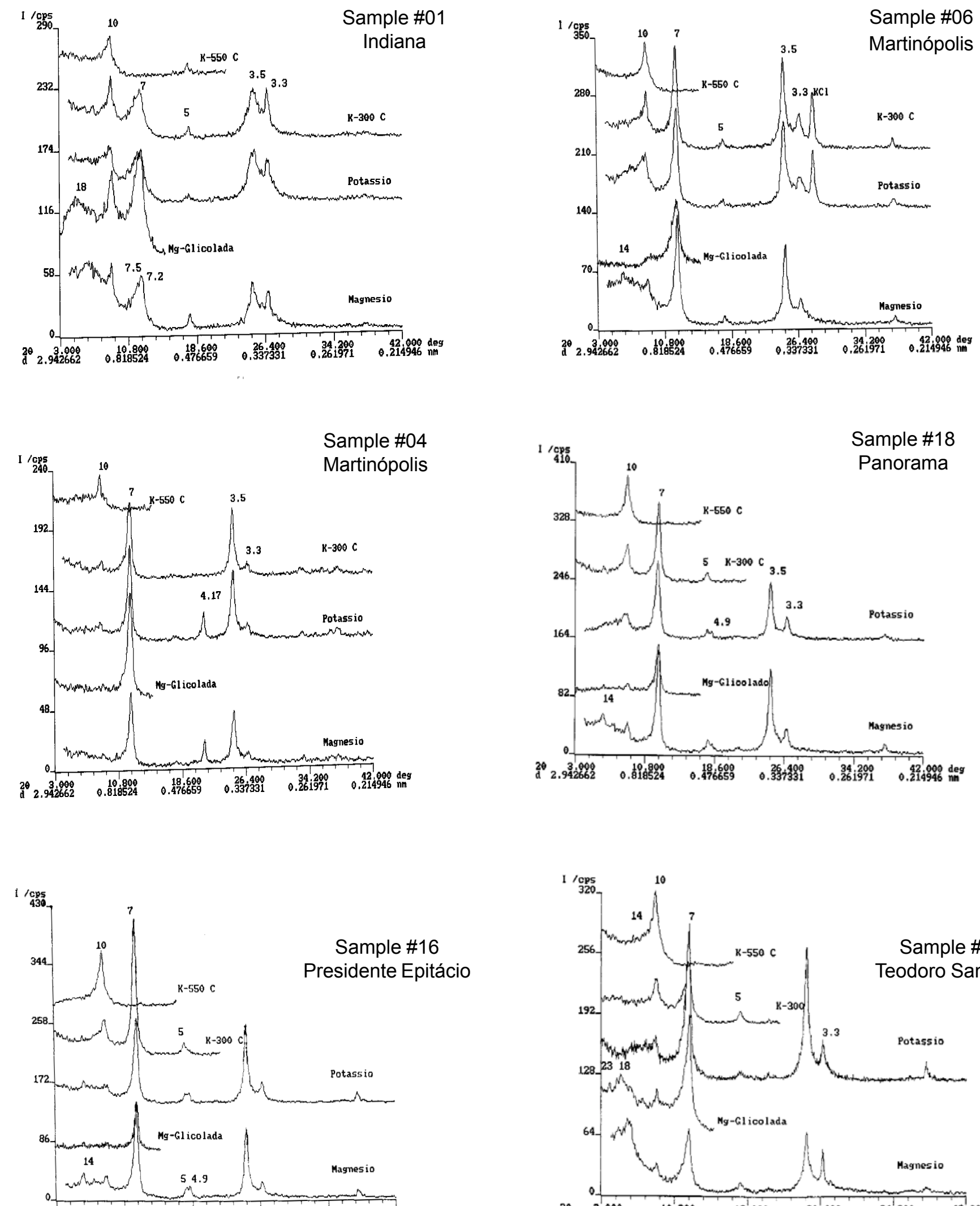

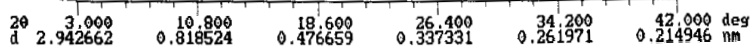

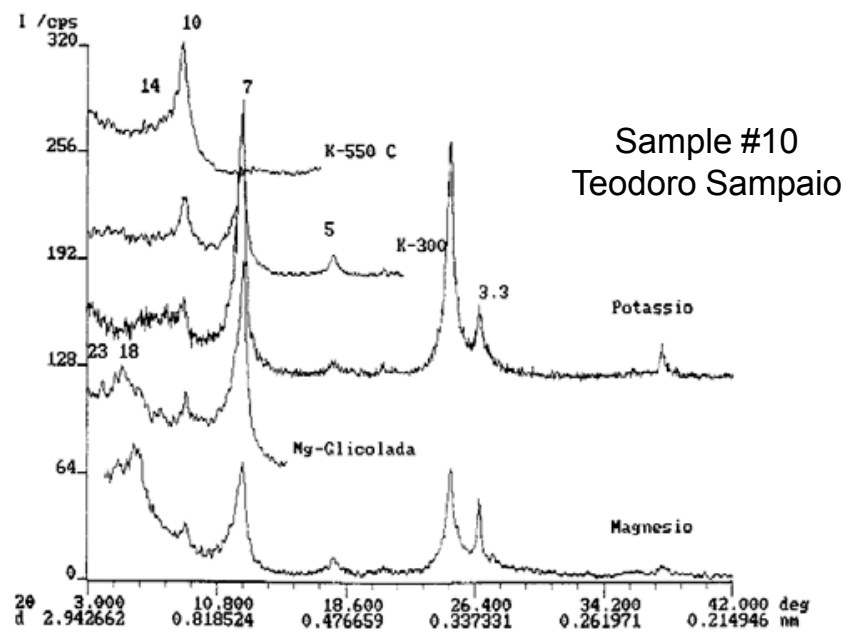

Figure 1: X-ray diffraction patterns of samples from: (a) \#01 Indiana, (b) \# 06 Martinópolis, (c) \# 04 Yellow clay - goethite, (d) \# 18 Panorama, (e) \# 16 Presidente Epitácio and (f) \# 10 Teodoro Sampaio.

[Figura 1: Difratogramas de raios X das amostras coletadas nas cerâmicas de: (a) \#01 Indiana, (b) \# 06 Martinópolis, (c) \# 04 argila rica em goetita, (d) \#18 Panorama, (e) \# 16 Presidente Epitácio e (f) \#10 Teodoro Sampaio.] 
Table II - Ideal particle-size distribution to each type of different product [7] .

[Tabela II - Distribuição granulométrica ideal para cada tipo de peça, de acordo com Pracidelli e Melchiades [7].]

\begin{tabular}{lccl}
\hline Type & Clay $\%$ & Silt $\%$ & Sand $\%$ \\
\hline Roof tiles & 30 to 40 & 20 to 50 & 20 to 40 \\
\hline Structural bricks & 20 to 30 & 20 to 55 & 20 to 50 \\
\hline Massive bricks & 15 to 20 & 20 to 55 & 25 to 55 \\
\hline
\end{tabular}

be necessary to make structural bricks or roof tile. To obtain the ideal composition these materials could be mixed with fine sand or material with low clay concentration. This could be applied to massive bricks and roof tiles, which are made by pressing the ceramic mass, meanwhile, according to the ceramists, high sand concentration can wear the extrusion machine used to make structural bricks. The silt concentration is ideal to all samples.

The samples plasticity limit ranges from 20.1 to $40.7 \%$. All samples are considered material with very high plasticity (PL > $15 \%$ ). The indicated PL for red ceramic ranges from 17.2 to $32 \%$ and for extrusion process the LP have to be between 26 to $32 \%$ [8]. Three samples (\#7, \#8 and \#16) have PL higher than $32 \%$ and six samples (\#01, \#06, and \#12 to \#15) have LP values smaller than $26 \%$. These nine samples have PL values unsuitable for production of the ceramic pieces by extrusion. High organic matter concentration or 2:1 minerals will result in high plasticity limits ( $\mathrm{PL}>32 \%$ ). It is important to know organic matter concentration because it will burn during the ceramic pieces firing process resulting in mass loss, pores formation and pieces with lower density.

Fig. 1 shows X-ray diffraction data of six samples. Each one shows five X-ray data of the same sample: (1) saturated with $\mathrm{Mg}$ and (2) with $\mathrm{Mg}+$ glycerol, (3) saturated with $\mathrm{K}$, (4) with $\mathrm{K}+$ heat treatment at $300{ }^{\circ} \mathrm{C}$ and (5) with $\mathrm{K}+$ heat treatment at $550{ }^{\circ} \mathrm{C}$. Kaolinite (peaks at 7 and $3.5 \AA$ ) is the major phase in all samples but occur with different concentrations and crystallinity. For example, Fig. I-a shows the X-ray pattern of sample \#01(Indiana) where kaolinite presents low crystallinity. Mica (10 and $5 \AA)$ is also observed in all samples and like kaolinite its concentration varies in each sample. Clays with 2:1 structure (14 $\AA$ ) were observed in all samples but \# 4 and some of these were identified as being smectite (montmorillonite, peak at $18 \AA$ is sample with $\mathrm{Mg}$ and glycerol): samples $\# 01$, \# 06, \# 09, \# 10 and \# 12 to \# 15 . The others 2:1 clays are chlorite or vermiculite or hydroxy-interlayered clay (HIV). The XRD data also indicate the presence of some mixed-layer or interstratified minerals. Quartz $(3.3 \AA)$ is observed in all samples and gibbsite ( $4.9 \AA)$, iron and titanium oxides are identified in many samples. The yellow clay (Fig. I-b, sample \# 04) has the major phase kaolinite and high concentration of goethite $(4.17 \AA)$. This clay is used to paint pottery, which will acquire red color after burn $\left(\mathrm{T} \approx 900^{\circ} \mathrm{C}\right)$ because goethite will transform in hematite (dark red color).

Before the Porto Primavera dam water inundated the floodplains it was possible to collect different types of clays selected by their colors. There were the yellow, black, gray, brown and sandy clays with different properties. These clays were mixed according to the final product desired. Most samples studied here were collected in clay deposits made before the inundation and they are composed of mixed materials.
The next step of this work will be to study the chemical composition and other techniques will be applied to obtain more data about these materials: differential thermal analysis, thermogravimetric analysis and technological tests after burn the pieces (resistance to traction, water absorption, mass loss and shrinkage).

\section{CONCLUSIONS}

1. All samples of raw material have high concentration of fine material (clay + silt) having high plasticity and can be used to make structural blocks, bricks or roof tiles;

2. All samples of raw material should be mixed with sandy material;

3. Kaolinite is the major phase in all samples and give a good plasticity necessary to produce these materials;

4. The concentration of 2:1 clays have to be controlled because these clays can produce cracks during the drying and/ or firing processes of the ceramic pieces;

5. Some samples have plasticity limit higher than the values (17.2 to $32 \%$ ) indicated to red ceramic and nine of then have PL unsuitable to the extrusion process;

6 . There is no homogeneity in the composition of the ceramic mass of these ceramics;

7. All samples mixed to make bricks and roof tiles have more clay than would be necessary.

\section{ACKNOWLEDGEMENTS}

The authors gratefully acknowledge FUNDUNESP and FAPESP (2000/07641-1) for the partial support of this work, CNPq for the student's scholarships and "Laboratório de Engenharia Civil" of the UNESP/FEIS for the plasticity limit analysis.

\section{REFERENCES}

[1] Companhia Energética do Estado de São Paulo- CESP. Reservatório de Porto Primavera: Estudo e Relatório de Impacto Ambiental - EIA/RIMA, Vol. I e II, (1992/93).

[2] EMBRAPA, Serviço Nacional de Levantamento e Conservação de Solo: Manual de Métodos de Análise de Solos, Rio de Janeiro - RJ, Brasil (1979).

[3] Instituto Agronômico de Campinas- IAC. Método de Análise de Solos para Fins de Fertilidade, Boletim n ${ }^{\circ} 81$, B. Van Ray \& A. J. B. Quaggio, Campinas - SP (1983).

[4] J. B. Dixon, G. N. White, Soil Mineralogy Laboratory Manual: Agronomy 626, Soil \& Crop Sciences Dept, Texas A \& M University, College Station-TX, USA (1996) 139.

[5] M. M. Moore, R. C. Reynolds Jr., X-ray Diffraction and the Identification and Analysis of Clay Minerals, 2nd. Ed. Oxford University Press, Oxford (1997) 378.

[6] Associação Brasileira de Normas Técnicas-ABNT. NBR 7180: Solo, Determinação de Limite de Plasticidade, Método de Ensaio, Rio de Janeiro-RJ, (1984).

[7] S. F. Pracidelli, F. G. Melchiades, Cerâmica Industrial 2, 1-2 (1997) 31.

[8] I. S. S. dos Santos, N. I. W. da Silva, H. J. Wildner, M. Boff, Anais do $39^{\circ}$ Congresso Brasileiro de Cerâmica, Águas de Lindóia, S P (1995) 407.

(Rec. 19/04/01, Ac. 14/11/01) 